\title{
Diel chl $a$ and phaeopigment cycles in a shallow tidal estuary: potential role of microzooplankton grazing
}

\author{
W. Litaker*, C. S. Duke**, B. E. Kenney, J. Ramus \\ Botany Department and Marine Laboratory, Duke University, Beaufort, North Carolina 28516, USA
}

\begin{abstract}
A persistent diel cycle in chl a biomass was observed in the Newport River estuary, North Carolina, USA during summer. Chl a concentrations were highest in the late afternoon (mean $22 \mu g 1^{-1}$ ) and least around dawn (mean $12 \mathrm{\mu g} \mathrm{l}^{-1}$ ). The day to night change in chl a was paralleled by a commensurate decline in volumetric cell count. This change in cell number was not correlated with wind resuspension, tidal dilution, or species composition differences, but rather is attributed to grazing. A diel cycle in $\mathrm{NH}_{4}{ }^{+}$concentration was also observed, due to temporal variations in uptake relative to water column remineralization. Ammonium concentrations reached a maximum $(>2 \mu M)$ several hours after dawn, then declined to a minimum $(<0.5 \mu M)$ by early afternoon as light-dependent uptake exceeded remineralization. By late afternoon remineralization again exceeded uptake and $\mathrm{NH}_{4}{ }^{+}$ concentration increased continually throughout the night. In vitro enrichments demonstrated that the daytime chl a increase was dependent on the early morning uptake of nitrogen, whether in the form of $\mathrm{NH}_{4}{ }^{+}, \mathrm{NO}_{3}{ }^{-}$or urea. Phaeopigment concentrations also followed a diel pattern with an early afternoon minimum and a near-dawn maximum, mirroring changes in chl a. This pattern was due to photodestruction of phaeopigment during the day and accumulation at night. Phaeopigment production was attributed to microzooplankton grazing. When converted to chl a equivalents, phaeopigment appearance accounted for $50 \%$ of the chl a loss.
\end{abstract}

\section{INTRODUCTION}

A pronounced diel cycle in chl a biomass was found in a series of 24 to $48 \mathrm{~h}$ studies during summer in the Newport River estuary North Carolina, USA. (Stearns et al. 1987). Chl a concentrations were minimal around dawn, rose to a maximum in late afternoon, then declined during the night. The daily maximum was approximately twice the nightly minimum. Preliminary investigation showed that, at most, $20 \%$ of the daily chl a decline was attributable to nocturnal grazing by $>75 \mu \mathrm{m}$ macrozooplankton (Stearns et al. 1987). Other causes of the diel chl a cycle were not determined. Therefore, this work was undertaken to identify factors driving the daily chl a variation, insofar as diel chl a cycles in the field are seldom observed (Sournia 1974).

- Present address: Department of Microbiology and Immunology, CB\# 7290,609 FLOB, University of North Carolina at Chapel Hill, Chapel Hill, North Carolina 27599, USA.

- Present address: Department of Biological Sciences, Wellesley College, Wellesley, Massachusetts 02181, USA
There is the possibility that these factors are unique to the Newport River estuary. On the other hand, similar mechanisms might operate in other estuarine systems, causing diel chl a cycles of comparable magnitude. These cycles may remain undetected because nocturnal sampling is seldom undertaken.

The majority of the field data reported here were gathered during the PULSE project, a fixed-point timeintensive study of estuarine variability (Litaker et al. 1987). Twenty-eight parameters were monitored on an hourly basis, $24 \mathrm{~h}$ per day, for $14 \mathrm{~d}$ to describe variations in meteorology, hydrology, water chemistry, chl a, and phaeopigment. Primary productivity and maximal $\mathrm{NH}_{4}{ }^{+}$uptake were measured at less frequent intervals. These data, in conjunction with a series of in vitro studies, and a second field study, allowed specific evaluation of (1) flushing rates, (2) cellular chl a cycling, (3) microzooplankton grazing and (4) daily wind suspension of benthic phytoplankton as contributors to the chl a cycle. Sufficiently high flushing rates could produce a diel chl a cycle by causing the estuary to function as a chemostat on a light/dark cycle. Daytime 
growth rate in excess of dilution would result in an increase in cell number, whereas declining growth rate at night would allow dilution to occur. Cellular cycling of chl a may also be important insofar as laboratory studies have shown that chl a cell ${ }^{-1}$ increases substantially during the day in some diatom species, then declines at night (Riper et al. 1979, Post et al. 1984). Such a diel change in chl a cell ${ }^{-1}$ would appear as a change in chl a biomass in situations where daily cell gains and losses are in equilibrium. Microzooplankton grazing might also contribute to the diel chl a cycle in 2 very different ways. First, preferential grazing at night would act in concert with the macrozooplankton grazing to reduce cell numbers (Stearns et al. 1987). Decreased grazing during the day would in turn allow for a greater net growth. Second, if microzooplankton grazing was steady throughout the day, it would represent a constant loss factor analogous to flushing. Changes in chl a would therefore follow increases or decreases in phytoplankton growth rates throughout the day. Diel variation in wind might also cause a chl a cycle in shallow systems like the Newport River estuary, where summertime wind speeds are generally highest in late afternoon and lowest predawn. Under these conditions, benthic diatoms may be resuspended in late afternoon and subsequently sink to the sediment-water interface at night.

In this paper we present field and in vitro data indicating much of the diel change in chl $a$ is due to cell growth and microzooplankton grazing. A minimal estimate of the microzooplankton grazing was obtained by measuring diel fluctuations in suspended phaeopigment concentration. The rationale for using changes in suspended phaeopigment to assess microzooplankton grazing rates is given in Soohoo \& Kiefer $(1982 a, b)$ and Welschmeyer \& Lorenzen (1985).

\section{MATERIALS AND METHODS}

Study site. The Newport River estuary $\left(34^{\circ} 46^{\prime} \mathrm{N}\right.$, $76^{\circ} 42^{\prime} \mathrm{W}$ ) is a shallow ( $1 \mathrm{~m}$ at MLW) southeastern coastal plains estuary which has a surface area of $27 \mathrm{~km}^{2}$, and is surrounded by Spartina alterniflora marshes (Williams 1966). Two lunar tides, with average amplitudes of $0.8 \mathrm{~m}$, occur each day. Current velocities average 0.3 to $0.4 \mathrm{~m} \mathrm{~s}^{-1}$, but range from zero flow for a few minutes at slack tide to more than $1 \mathrm{~m} \mathrm{~s}^{-1}$ at midtide. These currents are sufficiently energetic to destroy any vertical temperature or salinity gradients (Wolfe 1975) and allow benthic diatoms to be a common component of the assemblage (Thayer 1971).

Freshwater inputs are primarily from the Newport River which drains a $310 \mathrm{~km}^{2}$ watershed covered by lowland pine forest of the Croatan National Forest, pocosin swamps, and farmland. 'Blackwater', containing high concentrations of humic acids, drains from this watershed (Palumbo 1980). Seawater is supplied from the Atlantic Ocean via Beaufort Inlet and from Core and Bogue Sounds.

The horizontal salinity structure of the estuary is dependent on the flow of the Newport River. Rainfall is more abundant in the summer, but high rates of evapotranspiration greatly reduce runoff and river flow (Thornthwaite \& Mather 1955, 1957). Salinities increase and the system becomes 'lagoonal' under these conditions (Boynton et al. 1982). The major perturbations to this state are from large runoff events associated with the passasge of tropical storms.

August 1982 study. Field data collection was designed to establish the persistence of diel chl a cycles and to monitor associated environmental variables. In all, 28 variables, including meterology, hydrology, water chemistry, and phytoplankton physiology, were measured continually every hour for $2 \mathrm{wk}$. A 2 wk sampling period (10 to 24 August 1982) allowed for a complete precession of the tides so that tidal and diel periodicities were easily separated. This report includes the data on salinity, turbidity, average photosynthetically active radiation (PAR) in the water column, wind stress, residual dissolved ammonium $\left(\mathrm{NH}_{4}{ }^{+}\right)$, chlorophyll a (chl a) and phaeopigment. The location of the fixed station within the estuary is given in Fig. 1.

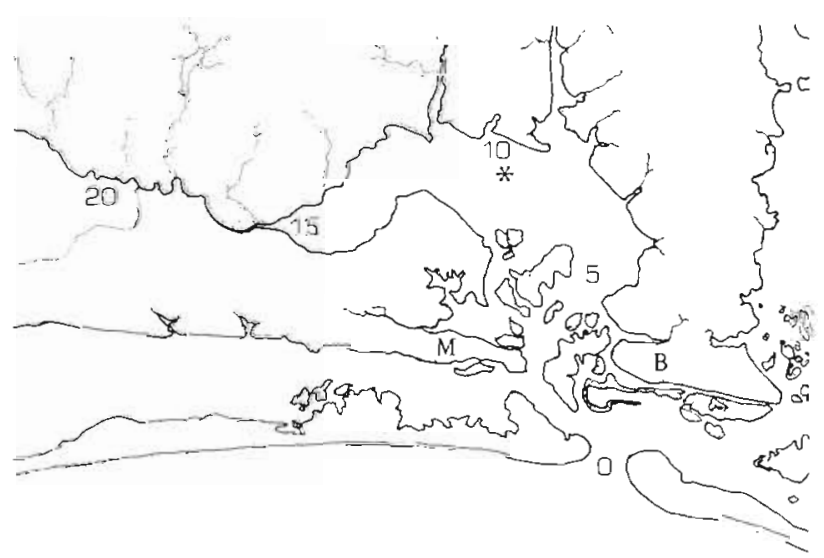

Fig. 1. Study site (*) and landmarks (B: Beaufort; M: Morehead City) of the Newport River estuary. Numbers along the axis of the estuary indicate $\mathrm{km}$ from Beaufort Inlet $(0)$

Salinity was determined at mid-depth by conductivity (Industrial Instruments RS-5-2 salinometer). Only mid-depth samples for all variables were taken because the water column was continually mixed. Turbidity was determined with a Turner Designs 40 nephelometer and expressed in NTU. Incident and submarine PAR were determined with a LiCor $192 \mathrm{~S}$ sensor and spherical collector coupled to a recording integrator. Attenuation coefficients $(k)$ were calculated 
from the Secchi depth (SD) and the relationship $k=1.35 \mathrm{SD}^{-1}$, determined empirically from simultaneous Secchi depth and light attenuation measurements. Average light levels in the water column were then calculated by the method of Riley (1957). Wind speed was measured with an anemometer and wind stress (dynes $\mathrm{cm}^{-2}$ ) estimated by $0.02 \times$ wind speed squared (Krauss 1978). Residual $\mathrm{NH}_{4}{ }^{+}$was determined from samples gently filtered through $0.45 \mu \mathrm{m}$ Gelman A/E filters and immediately developed using the phenol hypochlorite method (Koroleff 1970). Chl a was determined by fluorometric analysis (Turner Designs 10 fluorometer) of particulate material collected on Gelman A/E filters by gentle suction and extraction into $90 \%$ acetone. Phaeopigments were determined by acidification of the acetone extract.

Power spectra of the primary data sets were obtained by a Fourier transform of the autocovariance function using a Parzen smooth and 48 lags. This analysis partitions total variance into a number of equispaced frequencies from 0 to 0.5 in order to reveal the dominant periodicities (Platt \& Denman 1975). Spectra were normalized by dividing each frequency estimate by the total variance for comparative purposes. The spectral analysis program was written in Basic and was based on the algorithms presented in Otnes \& Enochson (1972), Dixon (1976, BMD02T), and Chatfield (1980). Normally the first step in spectral analysis is the prewhitening or transformation of the data set to make the time series stationary. However, the time series in this study, all of which were nonstationary, were initially analyzed without prewhitening in order to search for dominant harmonics in the data sets. This lack of prewhitening caused an overemphasis in amount of variation at low frequencies in time series where there is a general trend in the mean. As a check, first differencing was done on all the data sets to make them more stationary before spectral analysis. The same significant peaks were found in both the transformed and untransformed data sets in every case, though the relative magnitude of the peaks changed.

Data sets were also compared by cross-spectral analysis (Dixon 1976, BMD02T). Coherence squared $\left(\mathrm{coh}^{2}\right)$ estimates generated by this technique may be considered frequency-based $r^{2}$ between 2 data sets (Harris 1983). Cross-spectral analysis also gives phase estimates between data sets at each of the discrete frequencies. Significant levels for $\mathrm{Coh}^{2}$ were calculated by the method of Thompson (1979). The data sets for cross-spectral analysis were initially first differenced to make them more stationary. This reduced the possibility that large spurious cross-correlations were generated as a result of large autocorrelations within the individual time series (Gottman 1981). Once the significant cross-correlations were identified, the 2 series were further aligned to prevent bias due to rapid phase changes (Chatfield 1980). This procedure involved (1) identifying the $\operatorname{lag} x$ where the sample cross-correlation function had its largest value and (2) shifting one of the series a distance $x$ past the other, so that the peak in the cross-correlation function of the realigned series was at zero lag. First differencing and alignment increased the significance of the cross-correlations over those determined from the untransformed data. However, the same significant cross-correlations were found no matter which way the analysis was done, showing that despite the problem with nonstationarity, the cross-correlations were sufficiently strong even before data transformation.

In vitro enrichments. Four in vitro enrichments were undertaken to investigate the relationship between the early moming uptake of $\mathrm{NH}_{4}{ }^{+}$and midday chl a increase observed in the above study. Natural phytoplankton assemblages were gently filtered through $150 \mu \mathrm{m}$ Nitex netting, placed in culture vessels and incubated on a dock using neutral density filters at $30 \%$ PAR. Ambient temperatures were maintained by continually circulating estuarine water through the incubator. In 3 of the studies, 3 or $10 \mu M$ additions of either $\mathrm{NH}_{4}{ }^{+}, \mathrm{NO}_{3}{ }^{-}$, urea, glycine, or $\mathrm{PO}_{4}{ }^{-3}$ were given between 00:00 and 03:00 h. In the fourth experiment, additions of $\mathrm{NH}_{4}{ }^{+}, \mathrm{NO}_{3}{ }^{-}$and urea were given at midday to determine how timing of the nutrient addition would affect the observed variation in chl a.

August 1986 study. The Newport River estuary was sampled at the location described above at ca 16:00 and 04:00 h EST over 2 consecutive $24 \mathrm{~h}$ periods ( 8 to 10 August 1986). Sampling times corresponded to low tide. At each low tide, 3 samples were taken over a 40 min period to integrate spatial and temporal variation. Water temperature, salinity, $\mathrm{NH}_{4}^{+}$, chl a, and phaeopigment were determined using methods described above. Wind speed and direction were obtained from Cherry Point Marine Air Station, located $10 \mathrm{~km} \mathrm{NW}$ of the fixed station. Unfiltered water samples were returned to the laboratory where phytoplankton cells were concentrated and enumerated using the technique of Campbell (1973). This method involved concentrating a $10 \mathrm{ml}$ sample in a graduated conical centrifuge tube for $10 \mathrm{~min}$ at $825 \mathrm{~g}$. The supernatant was then carefully drawn off and the remaining cells gently resuspended in several drops. One of these drops was transferred to a clean slide, spread and stirred, and covered with a square $22 \mu \mathrm{m}$ coverslip. The slide was then moved back and forth in a predetermined pattern until ca 500 cells were identified. Concentration factors derived from the original volume of sample, the number of remaining drops after centrifugation, the percentage of the total coverslip area scanned, and the total cell count, were then used to calcu- 
late the number of cells $\mathrm{ml}^{-1}$. Cell counts determined in this manner were equal to or greater than those of Thayer (1971) which were done at the same time of the year using conventional settling techniques. Enumeration of fresh samples was far more descriptive than for samples preserved in Lugol's solution during the 1982 study.

\section{RESULTS AND DISCUSSION}

In August 1982 the estuary was nearly isohaline and salinities varied only sightly over the tidal cycle (Fig. 2). This is the usual situation during the summer when river flow is low. Turnover time under these conditions is on the order of $400 \mathrm{~d}$ (Kenney et al. 1988). Turbidity varied largely at the interday and tidal periods, being higher at low tide and in the late afternoon (Figs. 2 and 3). Average photosynthetic active radiation (PAR) in the water column was above that needed to saturate photosynthesis $\left(500 \mu \mathrm{E} \mathrm{m} \mathrm{m}^{-2} \mathrm{~s}^{-1}\right)$ on all days except 12 and 14 August (Litaker 1986). Mean wind stress varied from day to day, but over the course of the day was usually highest in the late afternoon (Figs, 2 and 4). The diel cycle in wind stress was significantly cross-correlated with the slight diel increase in turbidity, but not chl a or phaeopigment (Fig. 2; Table 1).

Ammonium concentrations varied in a diel pattern with a maximum several hours after dawn and a minimum during the mid-afternoon (Figs. 2 and 4). The pattern was due to light-dependent uptake exceeding water column regeneration during the day, whereas regeneration exceeded uptake at night (Litaker et al.

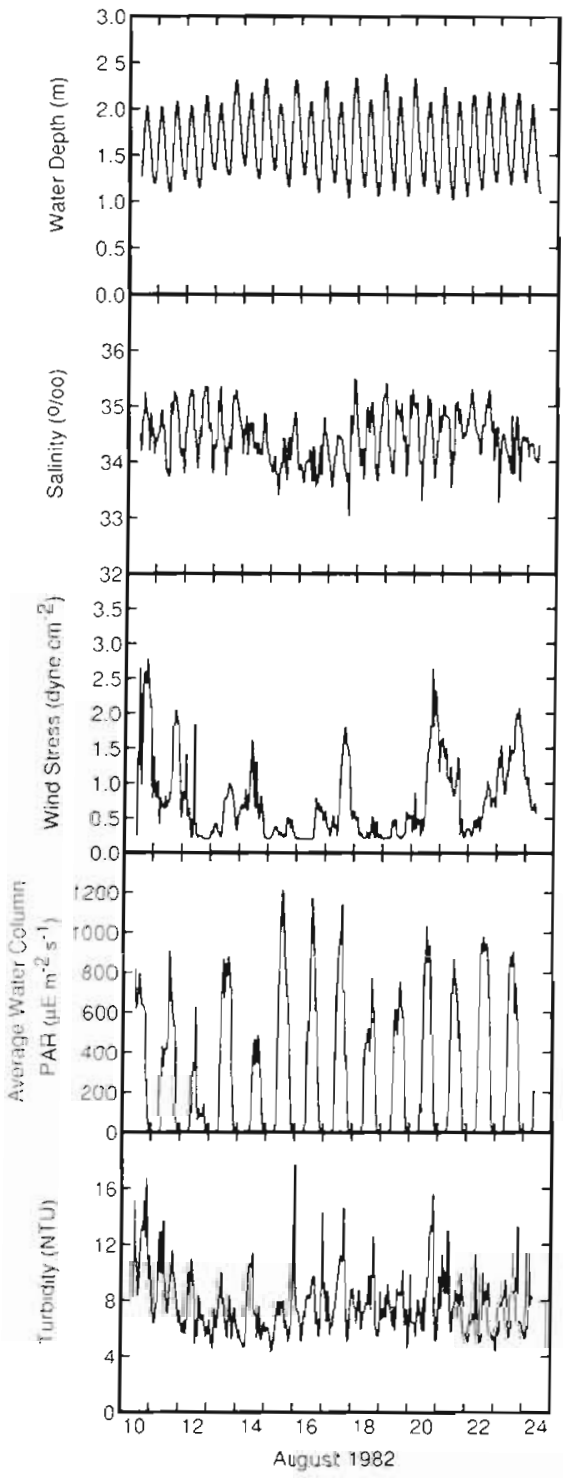

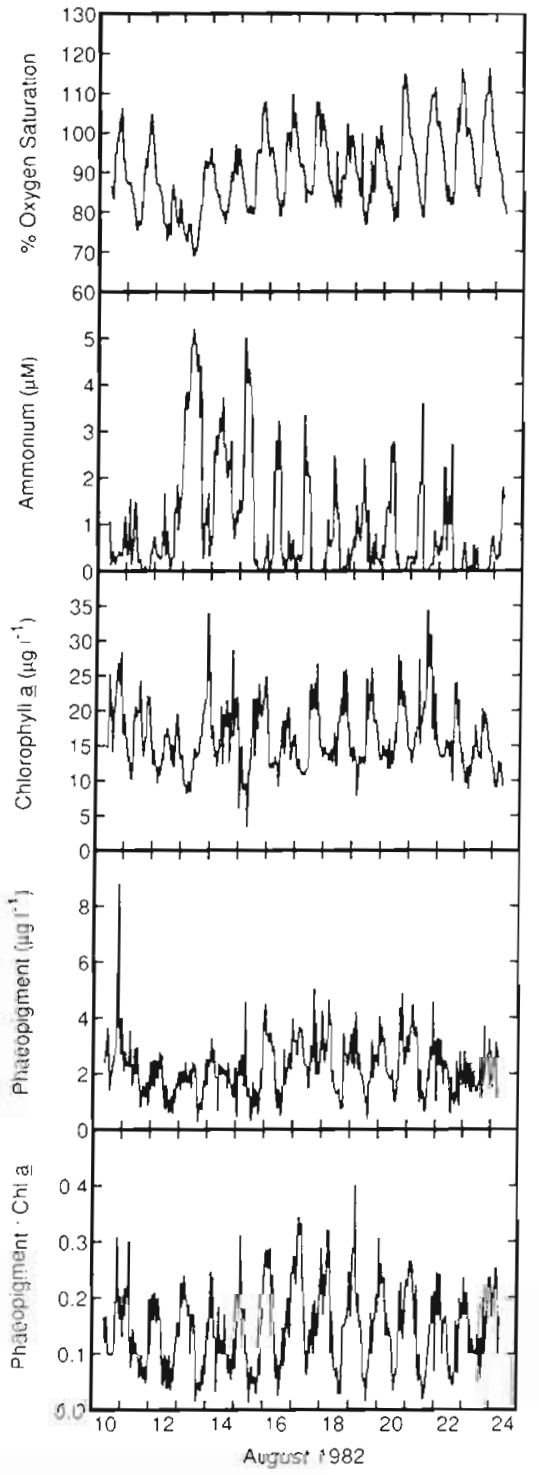

Fig. 2. Primary data sets for water depth $(\mathrm{m})$, salinity $(\%)$, wind stress (dyne $\mathrm{cm}^{-2}$ ). average water column irradiance $\left(u \mathrm{E} \mathrm{m}^{-2}\right.$ $\mathrm{s}^{-1}$ ), turbidity (NTU), oxygen saturation $(\%), \mathrm{NH}_{4}^{+}(\mu M)$, chl a $\left(\mu \mathrm{gl}^{-1}\right)$, phaeopigment $\left(\mu \mathrm{g}^{-1}\right)$, and phaeopigment:chl a ratio. Abscissa marks are at 00:00 h ESI 
Fig. 3. Power spectra from the data sets presented in Fig. 2. The 2 abscissa marks to the left of the $24 \mathrm{~h}$ mark represent the $96 \mathrm{~h}$ and $7 \mathrm{~d}$ period estimates, respectively
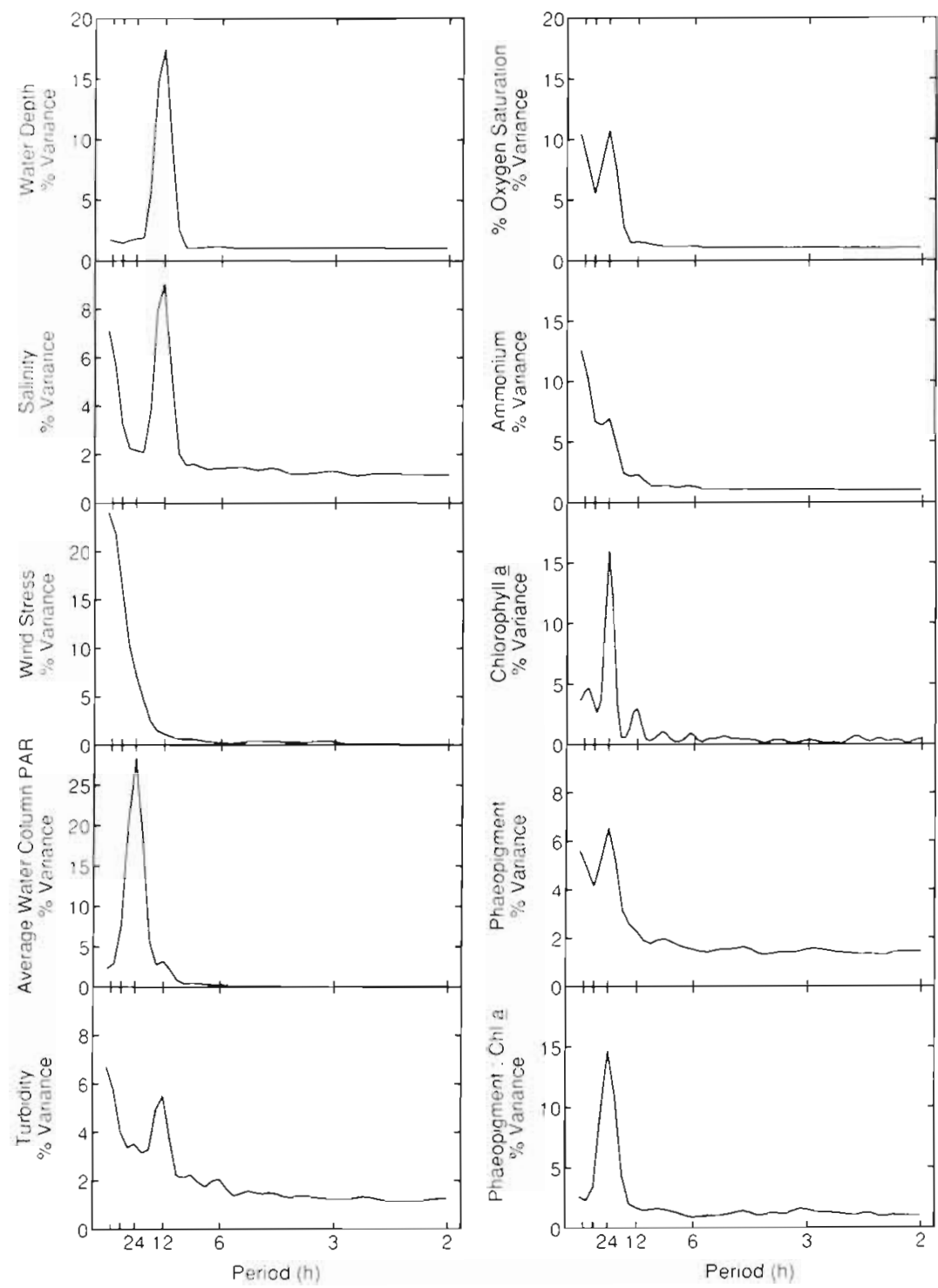

1987). Though the daily pattern in $\mathrm{NH}_{4}{ }^{+}$was consistent, there was considerable interday variation in the magnitude of the night-time peak. This interday $\mathrm{NH}_{4}{ }^{+}$ variation was correlated with the interday variations in insolation, with highest night-time peaks occurring following the 2 lowest insolation days (Fig. 2).

Chl a varied as observed in the preliminary studies (Figs. 2, 3 and 4; Stearns et al. 1987). Concentrations peaked in late afternoon and reached a minimum near dawn. This diel cycle was significantly correlated with the diel cycle in $\mathrm{NH}_{4}{ }^{+}\left(\mathrm{Coh}^{2}=0.744\right.$, Table 1), with the chl a peak occurring ca $10 \mathrm{~h}$ after the $\mathrm{NH}_{4}{ }^{+}$peak. Phaeopigment showed a significant diel variation as well (Figs. 2, 3 and 4). Concentrations reached a minimum in the late afternoon and a maximum predawn. This diel change in phaeopigment was significantly cross-correlated with $\mathrm{NH}_{4}^{+}\left(\operatorname{coh}^{2}=0.644\right)$ and chl $a\left(\operatorname{coh}^{2}=0.766\right)$ at $24 \mathrm{~h}$ period (Table 1$)$. The peak in chl a occurs ca $12 \mathrm{~h}$ after the peak in phaeopigment, whereas the peak in $\mathrm{NH}_{4}{ }^{+}$occurs only 3 to $4 \mathrm{~h}$ after the peak in phaeopigment (Figs. 2 and 4). Neither chl a, phaeopigment, nor $\mathrm{NH}_{4}{ }^{+}$were significantly crosscorrelated with wind at the $24 \mathrm{~h}$ or interday periods (Table 1). The lack of a correlation between chl a and wind stress (Fig. 2; Table 1) suggests that the diel cycle is not attributable to daily resuspension of diatoms that have settled to the sediment-water interface during the night. Phaeopigment was also lowest when wind speeds were highest indicating that wind resuspension of particulate matter was not a significant source of phaeopigment.

Thus chl a, phaeopigment and $\mathrm{NH}_{4}{ }^{+}$all underwent diel cycles that were significantly cross-correlated in the field (Table 1). However, mechanisms coupling 
Table 1. Periodicities where the squared coherence $\left(\operatorname{coh}^{2}\right)$ estimates between the $X$ and $Y$ series were significant. Phase values are an estimate of how much Series $X$ leads Series $Y$ in fractions of a circle. A phase of 0.5 corresponds to the maximal shift of $180^{\circ}$ Phase shifts of greater than 0.5 can be subtracted from 1.0 to obtain the phase by which the $Y$ series leads the $X$ series. Coh ${ }^{2}$ values were determined after series were transformed to make them more stationary, then aligned so that the peak in the crosscorrelation function was at zero lag. Critical values of $\operatorname{coh}^{2}$ at the $p<0.05,0.01$, and 0.001 significance levels are $0.393,0.536$ and 0.684 , respectively. NS: not significantly cross-correlated at any frequency

\begin{tabular}{|c|c|c|c|c|c|c|c|c|c|c|c|c|c|c|c|}
\hline \multirow{3}{*}{$\mathrm{X}$ Series } & \multicolumn{12}{|c|}{ Y Series } & \multirow{2}{*}{\multicolumn{3}{|c|}{ Phaeopigment }} \\
\hline & & nmonil & & & ind sti & & & urbidit & & & Chla & & & & \\
\hline & Period & $\mathrm{Coh}^{2}$ & Phase & Period & $\mathrm{Coh}^{2}$ & Phase & Period & $\mathrm{Coh}^{2}$ & Phase & Period & $\mathrm{Coh}^{2}$ & Phase & Period & $\mathrm{Coh}^{2}$ & Phase \\
\hline Salinity & 24.0 & 0.557 & 0.500 & & NS & & 12.0 & 0.601 & 0.452 & $\begin{array}{l}24.0 \\
12.0\end{array}$ & $\begin{array}{l}0.449 \\
0.659\end{array}$ & $\begin{array}{l}0.953 \\
0.451\end{array}$ & 12.0 & 0.490 & 0.629 \\
\hline Ammonium & & & & & NS & & & NS & & 24.0 & 0.744 & 0.453 & 24.0 & 0.644 & 0.850 \\
\hline Wind stress & & & & & & & $\begin{array}{l}96.0 \\
24.0\end{array}$ & $\begin{array}{l}0.604 \\
0.652\end{array}$ & $\begin{array}{l}0.033 \\
0.982\end{array}$ & & NS & & & NS & \\
\hline Turbidity & & & & & & & & & & $\begin{array}{r}24.0 \\
12.0 \\
6.0\end{array}$ & $\begin{array}{l}0.437 \\
0.608 \\
0.478\end{array}$ & $\begin{array}{l}0.035 \\
0.926 \\
0.997\end{array}$ & & NS & \\
\hline Chl a & & & & & & & & & & & & & 24.0 & 0.766 & 0.504 \\
\hline
\end{tabular}

these cycles were not explicit. Therefore, a series of in vitro perturbations of natural populations were undertaken to examine the relationship between morning $\mathrm{NH}_{4}{ }^{+}$ uptake, chl a increase, and phaeopigment decrease. Here, natural waters, with $>150 \mu \mathrm{m}$ zooplankton removed, were given additions to 0,3 , or $10 \mu M$ of $\mathrm{P}$ as $\mathrm{PO}_{4}{ }^{-3}$ or $\mathrm{N}$ as $\mathrm{NH}_{4}{ }^{+}, \mathrm{NO}_{3}{ }^{-}$, urea or glycine. Nitrogen species other than $\mathrm{NH}_{4}{ }^{+}$, the predominant form of $\mathrm{N}$ in the estuary, were tested for their ability to drive a chl a increase. In cultures receiving $\mathrm{NH}_{4}{ }^{+}, \mathrm{NO}_{3}{ }^{-}$, or urea additions the diel patterns in chl a and phaeopigment were similar to those observed in the estuary (Figs. 5 and 6 ), even with the exclusion of $>150 \mu \mathrm{m}$ zooplankton grazers and benthic filter feeders. Chl a increases were proportional to the amount of $\mathrm{N}$ added, with $\mathrm{NH}_{4}{ }^{+}$, $\mathrm{NO}_{3}{ }^{-}$and urea all being utilized equally well. Thus, the phytoplankton were not preferentially acclimated to utilize $\mathrm{NH}_{4}{ }^{+}$, the predominant nitrogen form.

Calculations presented here support the notion that chl a increases in the field were similarly proportional to $N$ availability and uptake. When the average $N$ uptake between dawn and the chl a maximum was converted to chl a equivalents using the average 8:1 $\mathrm{N}$ :chl a ratio for this estuary (Fisher 1975, Litaker et al. 1987), an estimated $9.7 \mu \mathrm{g}$ chl a $1^{-1}$ was produced during the period of chl $a$ increase. The actual average change was $8.2 \mu \mathrm{g} \mathrm{chl} \mathrm{a} \mathrm{l}^{-1}$. The agreement between the theoretical and actual increase therefore supports a stoichiometric coupling between $\mathrm{N}$ uptake and chl a increase.

Bacteria in the Newport River estuary successfully compete with phytoplankton for amino acids (Palumbo et al. 1983), which likely accounts for why glycine did not stimulate a significant chl a increase (Fig. 6). The bacteria, in turn, remineralize only 10 to $15 \%$ of the amino acids they assimilate in a form utilizable by phytoplankton (Palumbo et al. 1983). Thus amino acids, like glycine, are largely unavailable to phytoplankton.

Phosphate additions also failed to stimulate the daily chl a cycle (Fig. 6) because phytoplankton growth in this estuary is $\mathrm{N}$-limited at this time of the year (Thayer 1974).

The timing of the $\mathrm{N}$-nutrient addition appeared criti$\mathrm{cal}$ in determining the onset of chl a increase. When $\mathrm{NH}_{4}{ }^{+}, \mathrm{NO}_{3}{ }^{-}$and urea were added at noon to natural assemblages in vitro, all caused a dramatic increase in chl a throughout the night and into the next morning, after which chl a concentrations declined (Fig. 7). These data demonstrate that chl a synthesis can proceed in darkness. However nocturnal $N$ additions resulted in a lag in chl a production until morning (Fig. 6), indicating that light-dependent $\mathrm{N}$-assimilation is required for the chl a increase.

Another explanation for the diel chl a cycle directly addressed by the in vitro enrichment data is that of the balance between growth and flushing rates. The hypothesis is that growth rate exceeds tidal dilution during the day, but lags during the night. In this situation, the greater the daytime growth rates and flushing rates, the greater the amplitude of the day-night cycle of chl a biomass. The similarity in the chl a cycles between the field and in vitro observations where no dilution occurred, however, is evidence against a tidal dilution hypothesis. Furthermore, flushing rates were on the order of $400 \mathrm{~d}$ in the 1982 study (Kenney et al 1988), precluding dilution of more than a minor portion of the population day or night.

Elimination of wind resuspension and tidal dilution 
Fig. 4. Mean hourly measurements \pm 1 standard deviation for the data sets presented in Fig. 2. Solid bars at the top of the graphs indicate the dark period
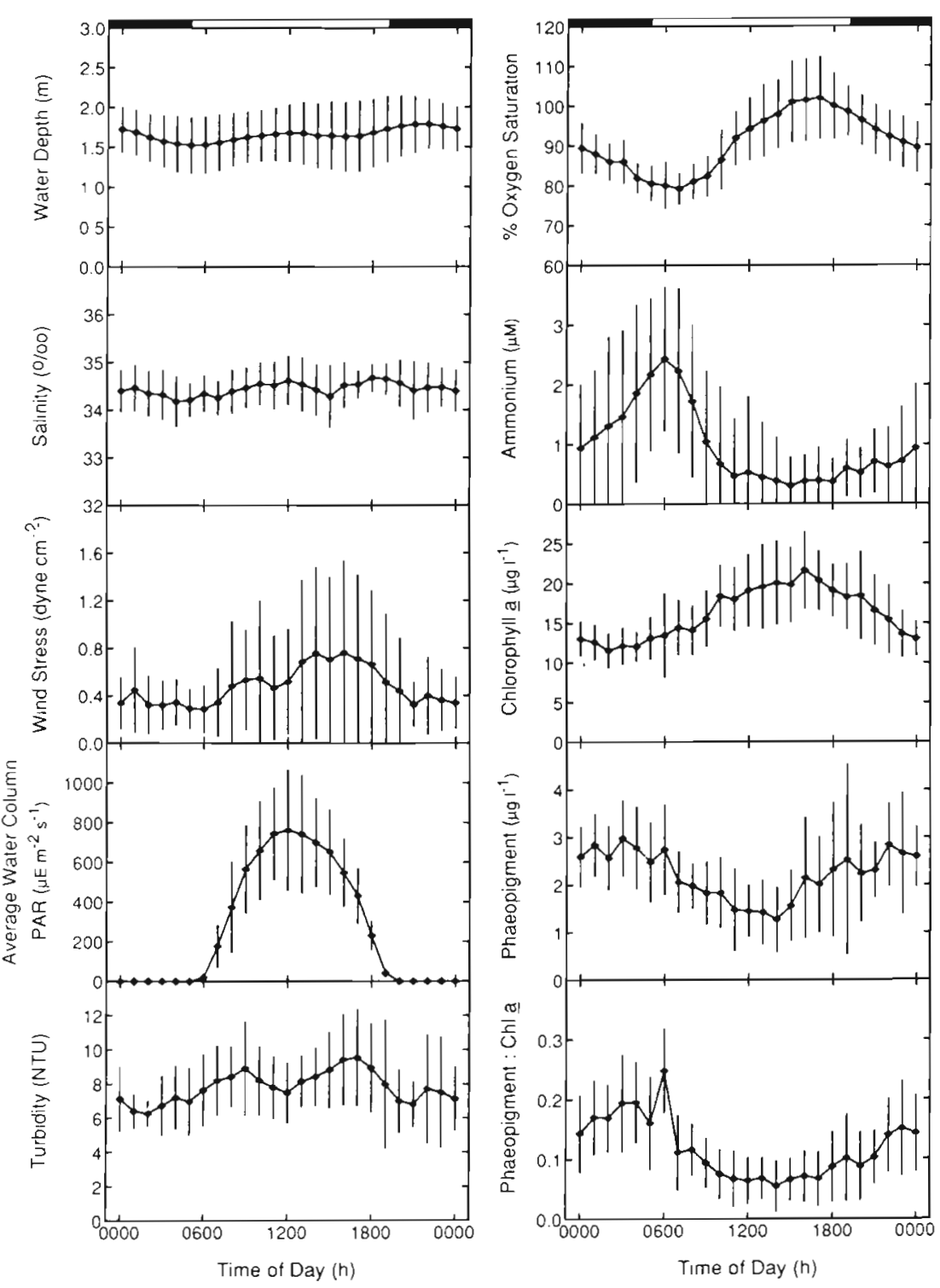

as causes of the diel chl a cycle leaves 2 other likely causes. The first is that chl a cell ${ }^{-1}$ increases following $\mathrm{N}$ uptake as chl a synthesis is stimulated, then declines in late afternoon as chl a degradation exceeds synthesis. Evidence for this process comes from a number of laboratory studies, whereby diatoms undergo a diel rhythm in chl a cell ${ }^{-1}$ above 15 to $20^{\circ} \mathrm{C}$ (Jorgensen 1966, Eppley et al. 1971, Riper et al. 1979, Hitchock 1980, Owens et al. 1980, Hunter \& Laws 1981, Post et al. 1984). In these studies, maximum cellular chl a concentrations were observed from 0 to $3 \mathrm{~h}$ before the end of the light period, whereas minimal concentrations occurred at the end of the dark period. Maximum cellular chl a concentrations were 1.2 to 2.0 times higher than the nightly minimum. The nightly declines in chl a cell ${ }^{-1}$ were not attributable to cell division as diatoms generally divide either during the light period or asynchronously throughout the day (Nelson \& Brand 1979, Riper et al. 1979, Owens et al. 1980). Instead the diel cycle was attributed to a diel variation in the synthesis and degradation rates of chl a (Riper et al. 1979). Thus, diatom-dominated assemblages which are in equilibrium with respect to losses and gains, such as the Newport River estuary in summer (Litaker et al. 1987), could show a diel chl a cycle based solely on changes in chl a cell ${ }^{-1}$.

A second prospect is that the balance between cell division and grazing shifted over the day such that cell numbers were reduced at night in both the field and in vitro observations. Theoretically, such an imbalance between grazing and cell division could occur in several ways. In the first case, grazing rates could be constant throughout the day and night. Rapid cell division in excess of grazing during the day would allow 


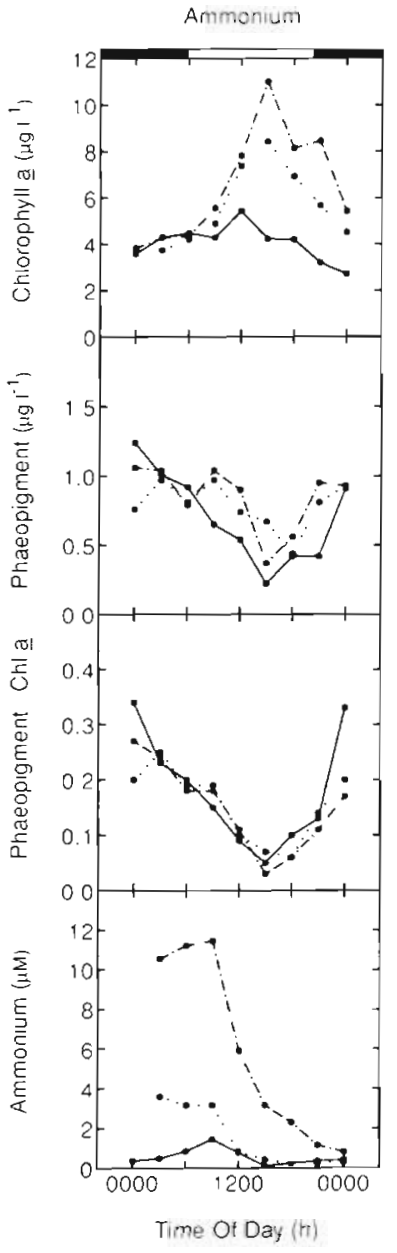

Fig. 5. An in vitro enrichment on 31 Aug $1982{ }_{i} \mathrm{NH}_{4}{ }^{+}$additions were given at 03:20 h. The data are chl a $\left(\mu \mathrm{g} \mathrm{l}^{-1}\right)$, phaeopigment ( $\left.\mu \mathrm{g} \mathrm{l}^{-1}\right)$, phaeopigment: chl a ratio and residual $\mathrm{NH}_{4}{ }^{+}$ $(\mu M)$ at each sampling period. Symbols correspond to control

$(\bullet \bullet), 3 \mu M(\bullet \bullet)$, and $10 \mu M(\bullet-\bullet) \mathrm{NH}_{4}{ }^{+}-\mathrm{N}$ additions

increases in cell numbers, whereas slower growth rates at night would cause declines when grazing exceeded growth. In the second case, grazing rates could be greater at night than the day. Most field situations dominated by diatoms are likely to involve both greater growth during the day, and some component of the grazing population that feed preferentially at night.

Unfortunately, sample preservation during the first field study and in vitro experiments was insufficient to obtain the accurate cell counts necessary to distinguish a change in chl a cell ${ }^{-1}$ from a change in cell number. To resolve the question, another field study was conducted in August 1986. Here, the estuary was sampled in late afternoon and predawn for 2 consecutive days and phytoplankton counted immediately. Enumeration of phytoplankton from fresh samples was more complete than from preserved samples. $\mathrm{Chl} a$ and $\mathrm{NH}_{4}{ }^{+}$patterns were consistent with the first field study (Table 2). Late afternoon chl a was twice predawn values, whereas cell numbers were nearly 3 times higher in late afternoon than predawn. Both these differences were replicable between days and were significant at the $p<0.001$ level (chl $a: \mathrm{df}=10, t=19.92 ;$ cells: $\mathrm{df}=6, t=12.7$; df determined by Welsch procedure given in Remington \& Schork 1970). Chl a cell ${ }^{-1}$ was also significantly higher at night ( $\mathrm{df}=9, t=5.0, p<0.01$ ) in opposition to laboratory studies showing predawn chl a cell ${ }^{-1}$ minima. Thus it is unlikely that cellular cycling of chl a contributes significantly to diel chl a variation observed in the estuary.

Chl a concentrations at each individual sampling period did not correlate with wind stress, again indicating that local mixing is not the cause of cell number variation (Table 2). Also the assemblage composition was similar day and night, eliminating vertical migration or advection of different water masses as causes for the diel change in cell number. Therefore, by elimination, grazing is the most likely cause of the diel variation in chl a. Fulton (1984) and Stearns (1986) have shown that most of the macrozooplankton in the estuary are nocturnal vertical migrators. To assess the impact of these grazers, Stearns et al. (1987) measured gut fullness of the dominant copepod species at $2 \mathrm{~h}$ intervals. By making gross overestimates of gut clearance rates and by assuming the greatest number of copepods ever measured locally at this time of the year, they estimated that grazing by $>75 \mu \mathrm{m}$ macrozooplankton, which are primarily copepods, can account for no more than $20 \%$ of the nocturnal decline in chl $a$. Thus the Stearns et al. study, and the in vitro enrichments where larger grazers were removed, imply that the greatest portion of phytoplankton are likely taken by $<75 \mu \mathrm{m}$ microzooplankton.

Minimal estimates of microzooplankton grazing were obtained in this study by (1) projecting the rate of nocturnal phaeopigment increases over the entire day and (2) using rates of photodestruction of water column phaeopigment (Welschmeyer \& Lorenzen 1985). The rationale for using phaeopigment changes as a measure of microzooplankton grazing rates is as follows. Phaeopigment does not accumulate in healthy cells or cells exposed to prolonged darkness (Hallergraeff \& Jeffery 1985, Welschmeyer \& Lorenzen 1985). Instead, ingestion and excretion of fecal material is the dominant process by which phaeopigment is formed (Soohoo \& Kiefer 1982a). However, once excreted, phaeopigment in fecal material from various grazers is not measured equally well by standard chl a sampling techniques. Macrozooplankton fecal pellets, for instance, are large and have sinking rates on the order of $100 \mathrm{~m} \mathrm{~d}^{-1}$. They therefore sink rapidly to the bottom and are not readily sampled by the Van Dorn bottle used to collect water samples in this study (Soohoo \& Kiefer 1982a, Welschmeyer et al. 1984). In contrast, 

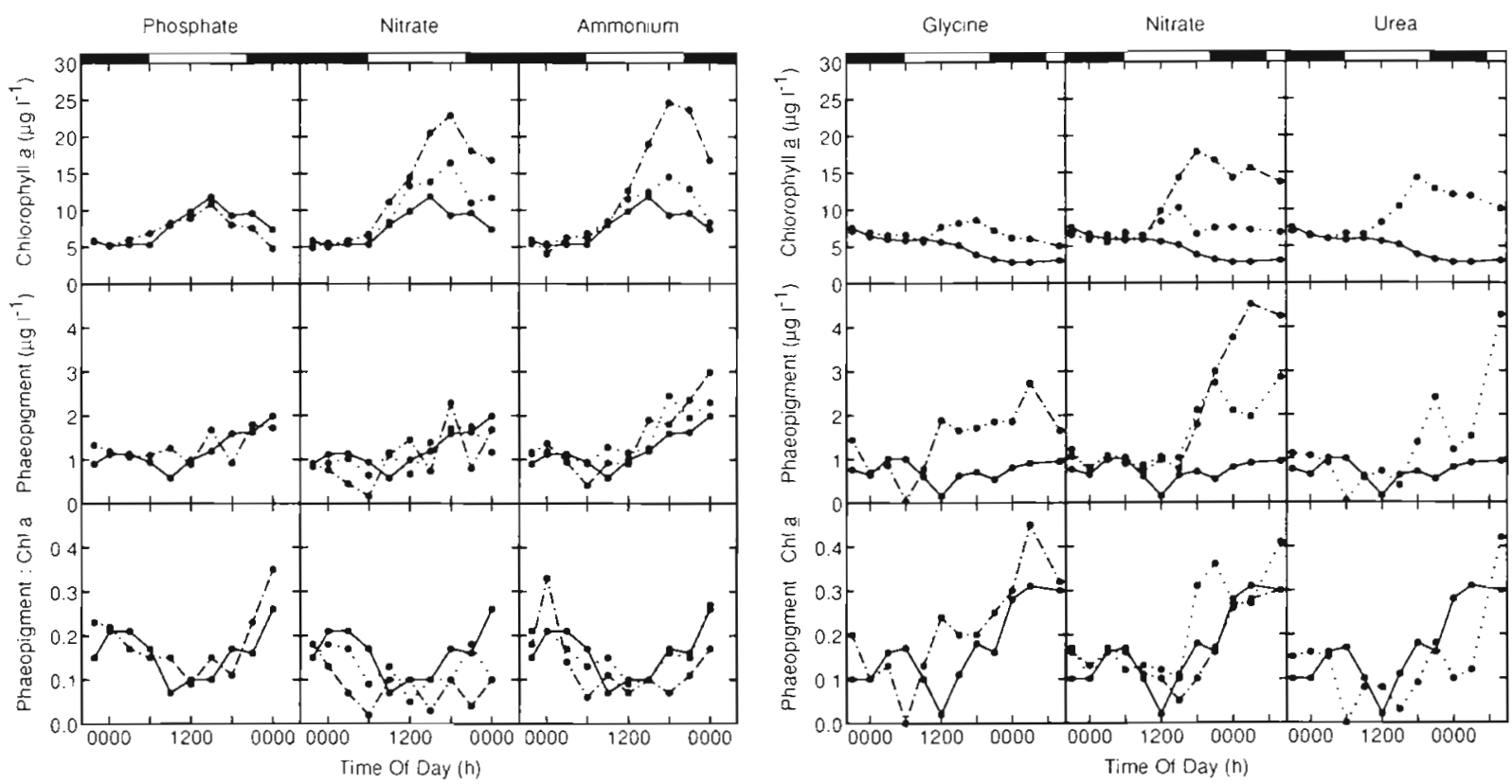

Fig. 6. Left: data from an in vitro enrichment on 26 and $27 \mathrm{Jul} 1982$; nutrient additions were given at 00:30 h on 27 Jul. Right: data from an in vitro enrichment on 30 and 31 Jul 1982; nutrient additions were given at 00:00 h on 30 Jul. Control ( $\bullet \bullet$ ) treatments received no nutrient addition. Additions of 3 and $10 \mu M \mathrm{~N}$ (ammonium, nitrate, glycine or urea) or $\mathrm{P}$ (phosphate) additions are denoted by $(\bullet \bullet)$ and $(\bullet-\cdots)$, respectively

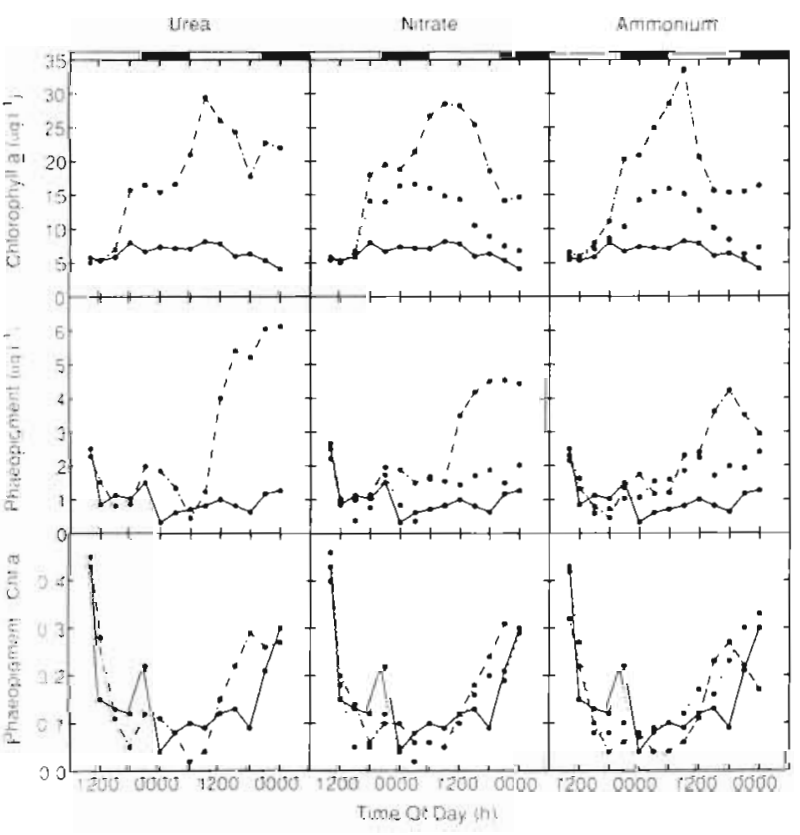

Fig. 7. An in vitro enrichment on 1 and 2 Aug 1982. Nutrient additions were given at 12:00 h on 1 Aug. Symbols for nutrient additions as in Fig. 6

sinking rates of microzooplankton fecal pellets and phytoplankton are less than $1 \mathrm{~m} \mathrm{~d}^{-1}$, i.e. they tend to remain in the water column. Hence, barring other inputs of phaeopigments such a resuspension of fecal pellets, chlorophyll grazed by microzooplankton con- stitutes the bulk of phaeopigments sampled by standard methods. Given that there is no evidence for diel inputs of phaeopigment via advection, tidal scour, or wind resuspension of fecal pellets (Table 1), phaeopigment measured in this study is therefore assumed to be produced by microzooplankton grazing.

A complicating factor that must be taken into account before using phaeopigment changes to measure microzooplankton grazing is the daily photodegradation of phaeopigment into a non-fluorescent compound. This process is accelerated at high (summer) water temperatures (Soohoo \& Kiefer 1982b). Photodestruction explains both the daily decline in phaeopigment and the decline in the phaeopigment/chl a ratio at midday, when the rates of phaeopigment destruction and chl a production are greatest (Fig. 2 and 4).

Given that photodestruction occurs, one way to objectively quantify phaeopigment increases is to measure at night. Thus the average nightly phaeopigment increases in the 1982 study were converted to chl a equivalents by dividing by 0.66 (Shuman \& Lorenzen 1975). When the average rate of phaeopigment increase at night was projected over an entire day an estimated $4.4 \mu \mathrm{g} \mathrm{chl} \mathrm{a} \mathrm{l}^{-1}$ was removed.

A second way to estimate microzooplankton grazing, based on the daily destruction of phaeopigment, is to use a numerical model employing the photodestruction constants for phaeopigment given in Soohoo \& Kiefer (1982b). The model employed in this study used: (1) the initial average phaeopigment concentration at 06:00 h 
Table 2. Data from the 1986 field study. Chl $a_{1}$ cell number, turbidity and $\mathrm{NH}_{4}^{+}$are given as mean \pm 1 standard deviation ( $N=3$ ). Average wind speed and wind stress are for the $3 \mathrm{~h}$ period prior to sampling period \pm 1 standard deviation. Phytoplankton enumeration data were divided into 5 broad categories including: (1) centric/solitary diatoms, many taxa, all with low abundance; (2) centric/colonial diatoms, primarily Skeletonema costatum and some Chaetoceros sp.; (3) nitzschioid/naviculoid diatoms, primarily Nitschia closterium and some Synedra sp.; (4) euglenids, primarily Eutreptia sp.; and (5) microflagellates including Amphidinium sp., Gymnodinium sp., Prasinocladus sp. and unidentified cryptomonads. Only a few large Peridinium cells were observed

\begin{tabular}{|c|c|c|c|c|c|c|}
\hline \multirow[t]{2}{*}{ Variable } & \multirow{2}{*}{$\begin{array}{c}8 \mathrm{Aug} \\
17: 00 \mathrm{~h}\end{array}$} & \multicolumn{2}{|c|}{9 Aug } & \multirow{2}{*}{$\begin{array}{l}10 \text { Aug } \\
05: 00 \mathrm{~h}\end{array}$} & \multicolumn{2}{|c|}{ Overall } \\
\hline & & $05: 00 \mathrm{~h}$ & $17: 00 \mathrm{~h}$ & & Day & Night \\
\hline $\begin{array}{l}\text { Chlorophyll concentration } \\
\left(\mu \mathrm{g} \text { chl } \mathrm{a} \mathrm{I}^{-1}\right)\end{array}$ & $\begin{array}{l}54.3 \\
(4.1)\end{array}$ & $\begin{array}{l}23.5 \\
(3.0)\end{array}$ & $\begin{array}{l}51.9 \\
(1.8)\end{array}$ & $\begin{array}{l}23.3 \\
(0.6)\end{array}$ & $\begin{array}{l}53.1 \\
(3.1)\end{array}$ & $\begin{array}{l}23.4 \\
(1.9)\end{array}$ \\
\hline $\begin{array}{l}\text { Cell density } \\
\text { (cells } \mathrm{ml}^{-1} \text { ) }\end{array}$ & $\begin{array}{l}10,004 \\
(1974)\end{array}$ & $\begin{array}{l}3102 \\
(252)\end{array}$ & $\begin{array}{l}10,287 \\
(784)\end{array}$ & $\begin{array}{l}2780 \\
(344)\end{array}$ & $\begin{array}{l}10,145 \\
(1352)\end{array}$ & $\begin{array}{l}2941 \\
(322)\end{array}$ \\
\hline $\begin{array}{l}\text { Chlorophyll cell } l^{-1} \\
\text { (ng chl a cell }{ }^{-1} \text { ) }\end{array}$ & $\begin{array}{c}5.5 \\
(0.8)\end{array}$ & $\begin{array}{c}7.6 \\
(1.3)\end{array}$ & $\begin{array}{c}5.1 \\
(0.6)\end{array}$ & $\begin{array}{l}8.5 \\
(1.1)\end{array}$ & $\begin{array}{c}5.3 \\
(0.7)\end{array}$ & $\begin{array}{c}8.1 \\
(1.2)\end{array}$ \\
\hline $\begin{array}{l}\text { Ammonium } \\
(\mu M)\end{array}$ & $\begin{array}{c}2.4 \\
(0.7)\end{array}$ & $\begin{array}{c}4.2 \\
(0.1)\end{array}$ & $\begin{array}{c}0.8 \\
(0.3)\end{array}$ & $\begin{array}{c}1.8 \\
(0.3)\end{array}$ & $\begin{array}{c}1.6 \\
(1.0)\end{array}$ & $\begin{array}{c}2.5 \\
(2.2)\end{array}$ \\
\hline $\begin{array}{l}\text { Average wind speed } \\
\left(\mathrm{m} \mathrm{s}^{-1}\right)\end{array}$ & $\begin{array}{c}9.3 \\
(0.5)\end{array}$ & $\begin{array}{c}4.1 \\
(1.0)\end{array}$ & $\begin{array}{c}7.0 \\
(1.1)\end{array}$ & $\begin{array}{c}5.8 \\
(1.1)\end{array}$ & $\begin{array}{l}8.2 \\
(1.4)\end{array}$ & $\begin{array}{c}5.0 \\
(0.3)\end{array}$ \\
\hline $\begin{array}{l}\text { Average wind stress } \\
\text { (dyne } \mathrm{cm}^{-2} \text { ) }\end{array}$ & $\begin{array}{c}1.7 \\
(0.1)\end{array}$ & $\begin{array}{c}0.4 \\
(0.2)\end{array}$ & $\begin{array}{c}1.0 \\
(0.3)\end{array}$ & $\begin{array}{c}0.7 \\
(0.2)\end{array}$ & $\begin{array}{c}1.4 \\
(0.5)\end{array}$ & $\begin{array}{c}0.5 \\
(0.3)\end{array}$ \\
\hline $\begin{array}{l}\text { Turbidity } \\
\text { (NTU) }\end{array}$ & $\begin{array}{c}45 \\
(0.3)\end{array}$ & $\begin{array}{c}16 \\
(0.1)\end{array}$ & $\begin{array}{c}29 \\
(0.2)\end{array}$ & $\begin{array}{l}14.5 \\
(0.1)\end{array}$ & $\begin{array}{l}37 \\
(0.3)\end{array}$ & $\begin{array}{c}15 \\
(0.1)\end{array}$ \\
\hline $\begin{array}{l}\text { Species composition } \\
\% \text { Centric/solitary diatoms }\end{array}$ & $\begin{array}{l}11.5 \\
(1.3)\end{array}$ & $\begin{array}{r}5.1 \\
(2.3)\end{array}$ & $\begin{array}{r}5.3 \\
(0.7)\end{array}$ & $\begin{array}{r}2.3 \\
(1.3)\end{array}$ & $\begin{array}{r}8.5 \\
(3.4)\end{array}$ & $\begin{array}{r}3.8 \\
(2.2)\end{array}$ \\
\hline$\%$ Centric/colonial diatoms & $\begin{array}{l}18.1 \\
(5.1)\end{array}$ & $\begin{array}{l}28.5 \\
(2.8)\end{array}$ & $\begin{array}{l}26.9 \\
(9.0)\end{array}$ & $\begin{array}{l}37.5 \\
(1.2)\end{array}$ & $\begin{array}{l}22.5 \\
(8.1)\end{array}$ & $\begin{array}{l}33.1 \\
(5.4)\end{array}$ \\
\hline$\%$ Nitzschioid/naviculoid diatoms & $\begin{array}{l}47.9 \\
(3.2)\end{array}$ & $\begin{array}{l}40.1 \\
(8.8)\end{array}$ & $\begin{array}{c}48.1 \\
(14.2)\end{array}$ & $\begin{array}{l}40.6 \\
(2.7)\end{array}$ & $\begin{array}{l}47.9 \\
(9.2)\end{array}$ & $\begin{array}{l}40.1 \\
(5.9)\end{array}$ \\
\hline$\%$ Euglenids & $\begin{array}{r}6.4 \\
(1.4)\end{array}$ & $\begin{array}{l}10.3 \\
(2.4)\end{array}$ & $\begin{array}{r}3.9 \\
(1.3)\end{array}$ & $\begin{array}{r}6.9 \\
(1.4)\end{array}$ & $\begin{array}{r}5.1 \\
(1.9)\end{array}$ & $\begin{array}{r}8.6 \\
(2.5)\end{array}$ \\
\hline$\%$ Microflagellates & $\begin{array}{l}16.1 \\
(1.0)\end{array}$ & $\begin{array}{l}16.0 \\
(0.4)\end{array}$ & $\begin{array}{l}15.8 \\
(4.0)\end{array}$ & $\begin{array}{l}12.7 \\
(1.6)\end{array}$ & $\begin{array}{l}16.0 \\
(2.6)\end{array}$ & $\begin{array}{l}14.4 \\
(2.0)\end{array}$ \\
\hline
\end{tabular}

(dawn), (2) the average water column PAR during each hourly period, and (3) the photodestruction constants derived by Soohoo \& Kiefer (1982a) for temperatures comparable to this study $\left(27 \pm 1^{\circ} \mathrm{C}\right)$. The model was then solved for the rate of phaeopigment production per hour that balanced the daily photodestruction such that the model returned to the same 06:00 h value on each day of the simulation. Total daily phaeopigment production was then converted to chl a equivalents. When the model was run using the highest photodestruction constant $\left(8.8 \mathrm{~m}^{2} \mathrm{E}^{-1}\right)$ measured by Soohoo \&

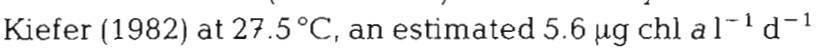
was consumed. Using the average photodestruction constant obtained with field samples taken at $27.5^{\circ} \mathrm{C}$ $\left(5.4 \mathrm{~m}^{2} \mathrm{E}^{-1}\right)$, an estimated $4.5 \mu \mathrm{g}$ chl a $\mathrm{l}^{-1} \mathrm{~d}^{-1}$ was consumed. This latter estimate is consistent with the one based on the nocturnal phaeopigment increase extrapolated over the entire day. The photodestruction constants used in these estimates bracket the average
$6.075 \mathrm{~m}^{2} \mathrm{E}^{-1}$ photodestruction constant used by Welschmeyer \& Lorenzen (1985)

Phaeopigment-based grazing estimates therefore account for roughly half of the daily $10 \mu \mathrm{g} \mathrm{chl} \mathrm{a} \mathrm{l}^{-1} \mathrm{~d}^{-1}$ decrease in chl a. Stearns et al. (1987) estimate that as much as another $20 \%$ of the daily chl a consumption (ca $2 \mu \mathrm{g} \mathrm{I}^{-1} \mathrm{~d}^{-1}$ ) is grazed by macrozooplankton (>75 um fraction) whose fecal pellets would not be quantitatively sampled by the horizontal Van Dorn bottle used in this study. Possible sources of the remaining chl a loss may be (1) consumption by benthic filter feeders, thought to be important loss factors in certain shallow water systems (Officer et al. 1982), (2) consumption by herbivorous fish, and (3) dissolution of phaeopigment from microzooplankton fecal pellets.

No direct measurements of grazing rates by benthic filter feeders have been done in this estuary. Thus, both the extent and pattern of grazing by these organisms is unknown. What grazing is done by subtidal filter feed- 
ers would likely remove cells continually throughout the day unless predation by fishes, which are visual predators, favors nocturnal feeding. Intertidal filter feeders, in turn, would cause a cyclical loss at each high tide or at nocturnal high tides if the pattern is influenced by fish predation.

The dominant planktivorous fish species in this estuary is the Atlantic menhaden Brevoortia tyrannus. An upper limit to the grazing by this species can be estimated by multiplying the maximal concentration of juvenile menhaden found at the study site in August (500 ind. per $6070 \mathrm{~m}^{3}$; Pernell Lewis pers. comm.) by an average estimate how quickly water is swept clear of phytoplankton by juvenile fish $\left(0.9 \mathrm{l} \mathrm{min}^{-1}\right.$ ind. $\left.{ }^{-1}\right)$ taken from Friedland et al. (1984). Using these data, 1 juvenile menhaden would clear about $1.3 \mathrm{~m}^{3} \mathrm{~d}^{-1}$ or ca $11 \%$ of the $12.1 \mathrm{~m}^{3}$ each fish occupies at maximal density. Menhaden could therefore potentially graze a significant, but minor portion of the chl a biomass. Because juvenile menhaden feed primarily during daylight (Peters \& Kjelson 1975) their grazing activity would remove cells during the daily chl a increase, thereby dampening the diel chl a cycle. Reduced nocturnal grazing also implies that juvenile menhaden do not contribute significantly to the night-time chl a decline or phaeopigment increase.

If phaeopigment dissolves from microzooplankton fecal pellets, then standard chl a techniques, which only measure phaeopigment in particulate material trapped on filters, will underestimate phaeopigment production. Thus the greater the rates of phaeopigment dissolution, relative to the rates of photodestruction during the day or rates of phaeopigment accumulation at night, the more severely changes in phaeopigment underestimate microzooplankton grazing rates. Currently, rates of phaeopigment dissolution from microzooplankton fecal pellets are unknown.

The extent to which microzooplankton grazing varies on a diel basis could not be determined definitively from these data. However, the nightly increase in phaeopigment accounted for less than half the daily production indicating more constant grazing over the day, with greater daytime losses due to the long photoperiod. This would imply that phytoplankton growth exceeds microzooplankton grazing during the day and that both microzooplankton and macrozooplankton grazing reduces cell numbers at night. The nearly 3 fold diel variation in cell numbers underscores the effect of grazing in controlling species composition during the warmer months. Excretion from this high grazing activity would also account for the high rates of water column $\mathrm{NH}_{4}{ }^{+}$remineralization observed at this time (Litaker et al 1987). This diel variation in grazing may be important in triggering diel cycles in $\mathrm{NH}_{4}{ }^{+}$, chl $a$ and phaeopigment in other estuarine systems during the warmer parts of the year. A likely reason that these cycles have not been previously observed is that sampling intervals employed in most studies are too long to allow the cycles to be recognized, or to allow contaminating advective events to be filtered out.

\section{CONCLUSIONS}

(1) A persistent diel pattern in chl a was observed for a 2 wk period in August 1982, in the Newport River estuary. Chl a concentrations peaked in late afternoon and declined to nearly half the afternoon maximum by dawn.

(2) This decrease in chl a between late afternoon and dawn was paralleled by a nearly 3 -fold decrease in cell number.

(3) Residual dissolved ammonium concentrations also showed a diel rhythm, with lowest concentrations $(<0.5 \mu M)$ in the afternoon and highest concentrations, $(>2.0 \mu M)$ several hours after dawn. The daytime decline was due to light-dependent uptake exceeding remineralization, whereas at night remineralization exceeded uptake.

(4) A series of in vitro enrichments demonstrated that the increase in chl a during the day is dependent on $\mathrm{N}$ availability and uptake in the morning.

(5) The diel variation in chl a could not be explained by wind speed variations, tidal dilution, or by changes in chl a cell ${ }^{-1}$ or species composition.

(6) Variations in cell number and phaeopigment concentrations, instead, suggest that microzooplankton grazing and diel variations in phytoplankton growth were responsible for a significant portion of the daily chl a variation.

Acknowledgements. This work was supported by NSF grant OCE-81-13328 to J. R. We thank Meg Gatling for her help with the in vitro experiments in 1982 and Seth J. Ramus for his able assistance in August 1986. Officers at Cherry Point Marine Air Station kindly provided wind speeds for the August 1986 study. We thank Ms Jean Holliday for careful typing of the manuscript. Todd Lewis gave initial assistance with PostScript programming for the figures.

\section{LITERATURE CITED}

Boynton, W. R., Kemp, W. M., Keefe, C. W. (1982). A comparative analysis of nutrients and other factors influencing estuarine phytoplankton production. In: Kennedy, V. S. (ed.) Estuarine comparisons. Academic Press, New York, p. $69-90$

Campbell, P. H. (1973). Studies on brackish water phytoplankton. Sea Grant Publication UNC-SG-73-07. National Technical Information Service. U.S. Department of Commerce, Springfield, Virginia

Chatfield, C. (1980). The analysis of time series: an introduction. Chapman and Hall, New York

Dixon, W. J., ed. (1976). BMD Biomedical Computer Programs. University of California Press, Berkley, California

Eppley, R. W., Rogers, J. N., McCarthy, J. J. (1971). Light/dark periodicity in nitrogen assimilation of the marine phyto- 
plankter Skeletonema costatum and Coccolithus huxleyi in N-limited chemostat culture J. Phycol 7: 150-154

Fisher, T R. (1975). Bioenergetics, growth, and reproduction of the solitary tunicate Styella plicata. Ph. D. dissertation Duke University, Durham, North Carolina

Friedland, K. D., Haas, L. W., Merriner, J. V (1984). Filtering rates of the juvenile Atlantic menhaden Brevoortia tyrannus (Pisces: Clupeidae), with consideration of the effects of detritus and swimming speed. Mar. Biol. 84: 109-117

Fulton, R. S., III. (1984). Distribution and community structure of estuarine copepods. Estuaries 7: 38-50

Gottman, J. M. (1981). Time-series analysis: a comprehensive introduction for social scientists. Cambridge University Press, New York

Hallegraeff, G. M., Jeffrey, S. W (1985). Description of new chlorophyL $a$ alteration products in marine phytoplankton. Deep Sea Res. 32: 697-705

Harris, G. P. (1983). Mixed layer physics and phytoplankton populations: studies in equilibrium and non-equilibrium ecology. In: Round, F. E., Chapman, D. J. (eds.) Progress in phycological research, Vol. II. Elsevier Science Publishers B. V., Amsterdam, p. 1-52

Hitchcock, G. L. (1980). Influence of temperature on the growth rate of Skeletonema costatum in response to variations in daily light intensity. Mar Biol. 57: 261-269

Hunter, B. L., Laws, E. A. (1981). ATP and chlorophyll a as estimators of phytoplankton carbon biomass. Limnol. Oceanogr. 26: 944-956

Jorgensen, E. G. (1966). Photosynthetic activity during the life cycle of synchronous Skeletonema cells. Physiologia Plantarum 19: 789-799

Kenney, B. E., Litaker, W., Duke, C. S., Ramus, J. (1988) Community oxygen metabolism in a shallow tidal estuary Estuar. coast. Shelf Science. (in press)

Koroleff, I. (1970). Direct determination of ammonia in natural waters as indophenol blue. Information on techniques and methods for seawater analysis. Interlab. Rep. Cons. perm. int. Explor. Mer 3: 19-22

Krauss, J. A. (1978). Introduction in physical oceanography. Prentice-Hall, Inc., Englewood Cliffs, New Jersey

Litaker, W. (1986). Dynamics of a well-mixed estuary. Ph. D dissertation, Duke University, Durham, North Carolina

Litaker, W., Duke, C. S., Kenney, B. E., Ramus, J. (1987). Short-term environmental variability and phytoplankton abundance in a shallow tidal estuary. I. Winter and Summer Mar. Biol. 96: 115-121

Nelson, D. M., Brand, L. E. (1979). Cell division periodicity in 13 species of marine phytoplankton on a light:dark Cycle. J. Phycol. 15: 67-75

Officer, C. B., Smayda, T J., Mann, R. (1982). Benthic filter feeding: A natural eutrophication control. Mar Ecol. Prog. Ser. 9: 203-210

Otnes, R. K., Enochson, L. E. (1972). Digital time series analysis. John Wiley and Sons, New York

Owens, T G., Falkowski, P. G., Whitledge, T E. (1980). Diel periodicity in cellular chlorophyll content in marine diatoms. Mar. Biol. 59: 71-77

Palumbo, A. V (1980). Dynamics of bacterioplankton in the Newport River estuary. Ph. D. dissertation, North Carolina State University, Raleigh, North Carolina

Palumbo, A. V., Ferguson, R. L., Rublee, P. A. (1983). Efficient utilization of dissolved free amino acids by suspended marine bacteria. J. exp mar Biol. Ecol 69: 257-266

Peters, D. S., Kjelson, M. A. (1975). Cansumption and utilization of food by vanous postlarval and juvenile fishes of
North Carolina estuanes. In: Cronin, L. E. (ed.) Estuarine research, Vol. I. Chemistry, biology and the estuarine system. Academic Press, New York, p. 448-471

Platt, T., Denman, K. L. (1975). Spectral analysis in ecology. A. Rev. Ecol. Syst. 6: 189-210

Post, A. F., Dubinsky, Z., Wyman, K., Falkowski, P. G. (1984). Kinetics of light-intensity adaptation in a marine planktonic diātom. Mar. Biol. 83: 231-238

Remmington, R. D., Schork, M. A. (1970). Statistics with applications to the biological and health sciences. Printice-Hall, Inc. Englewood Cliffs, New Jersey

Riley, G. A. (1957). Phytoplankton of the north central Sargasso Sea. Limnol. Oceanogr. 2: 252-270

Riper, D. M., Owens, T G., Falkowski, P. G. (1979). Chlorophyll turnover in Skeletonema costatum, a marine plankton diatom. Pl. Physiol. 64: 49-54

Shuman, F. R., Lorenzen, C. J. (1975). Quantitative degradation of chlorophyll by a marine herbivore. Limnol. Oceanogr. 20: 580-586

Soohoo, J. D., Kiefer, D. A. (1982a). Vertical distribution of phaeopigment - I. A simple grazing and photooxidative scheme for small particles. Deep Sea Res. 29: 1539-1551

Soohoo, J. D., Kiefer, D. A. (1982b). Vertical distribution of phaeopigment - II. Rates of production and kinetics of photooxidation. Deep Sea Res. 29: 1553-1563

Sournia, A. (1974). Circadian periodicities in natural populations of marine phytoplankton. Adv. mar. Biol. 12: 325-389

Stearns, D. E. (1986). Copepod grazing behavior in simulated natural light and its relation to nocturnal feeding. Mar. Ecol. Prog. Ser. 30: 65-76

Stearns, D. E., Litaker, W., Rosenberg, G. (1987). Impacts of zooplankton grazing and excretion on short-interval fluctuations in chlorophyll $a$ and nitrogen concentrations in a well-mixed estuary. Estuar. coast. Shelf Sci. 24: 305-325

Thayer, G. W. (1971). Phytoplankton production and the distribution of nutrients in a shallow unstratified estuarine system near Beaufort, N. C. Chesapeake Sci. 12: 240-253

Thayer, G. W (1974). Identity and regulation of nutrients limiting phytoplankton production in the shallow estuaries near Beaufort. N.C. Oecologia (Berl.) 14: 75-92

Thompson, R. O. R. Y (1979). Coherence significance levels. J. Atmos. Sci. 36: 2020-2021

Thornthwaite, C. W. Mather, J. R. (1955). The water balance. Publications in Climatology Vol. 8, No. 1, Centerton, New Jersey, p. 1-86

Thornthwaite, C. W., Mather, J. R. (1957). Instructions and tables for computing potential evapotranspiration and the water balance. Publications in Climatology, Vol. 10, No. 3, Centerton, New Jersey, p. 185-311

Welschmeyer, N. A., Lorenzen, C. J. (1985). Chlorophyll budgets: zooplankton grazing and phytoplankton growth in a temperature fjord and the Central Pacific Gyres. Limnol. Oceanogr. 30: 1-21

Welschmeyer, N. A., Copping, A. E., Vernet, M., Lorenzen, C. J. (1984). Diel fluctuation in zooplankton grazing rates as determined from the downward vertical flux of phaeopigments. Mar. Biol. 83: 263-170

Williams, R. B. (1966). Annual phytoplanktonic production in a system of shallow temperate estuaries. In: Bames, $\mathrm{H}$. (ed.) Some contemporary studies in marine sciences. George Allen and Unwin Ltd., London, England, p. 699-716

Wolfe, D. A. (1975). Modeling the distribution and cycling of metallic elements in estuarine ecosystems. In: Cronin, L. E. (ed.) Estuarine research. Vol 1., Academic Press, New York, p. 645-671 